\title{
Analysis of Issues of Vietnam's Joining the TPP
}

\author{
Jungran Cho*
}

\begin{abstract}
Vietnam has been actively integrated into a multilateral trading system based on its accession to the WTO and the implementation of a series of ASEAN+1 FTAs. Now Vietnam is negotiating to be a member of the Trans-Pacific Partnership (TPP) agreement, which is a region-wide FTA in the Asia-Pacific region, and a total of 21 working groups have been negotiating 29 chapters of the TPP. This paper tries to assess major issues of Vietnam's joining the TPP, and to draw policy implications such as initiatives for Vietnam's acceleration of its renovation and economic restructuring programs; and domestic measures for facilitating FTA implementation by firms and enhancing the country's implementation capacity.
\end{abstract}

Key Words: Free Trade Agreement, Trans-Pacific Partnership Agreement, Vietnam

JEL codes: F13, F23

\footnotetext{
* Research professor, JRI, Inha University
} 


\section{Introduction}

FTAs have become popular in across the world and beenrecognized as one of the most efficient ways to promote the integration of countries into the world economy. To a certain extent, the world economy has witnessed strong competition in concluding FTAs. In particular, as the U.S. has led the Trans-Pacific Partnership (TPP) agreement, a region-wide FTA in the Asia-Pacific region, some competition for joining the TPP has been observed. There are now 12 countries (including Vietnam) negotiating the TPP, and its conclusion has been somewhat delayed, although these countries have announced the target date for concluding the TPP several times (by November 2011, by the end of 2012, and now by the end of 2013). Recent ministerial meeting in Hawaii, July 2015 was regarded as the final chance for concluding the negotiation under the Obama Administration, but the TPP countries could not conclude the negotiation.

Vietnam has been actively integrated into a multilateral trading system based on its accession to the WTO and the implementation of a series of ASEAN+1 FTAs. In the last three decades, Vietnam has signed and negotiated many trade agreements with about 60 countries, and this development has provided many foreign firms with more open and business-friendly environments in Vietnam. Foreign direct investment has been a prime source of Vietnam's industrial and economic development, and access to international markets has allowed Vietnamese firms to export a wide range of products ranging from agricultural commodities to sophisticated products such as mobile phones, providing increased job opportunities.

Accelerating trade liberalization in a sustainable and active manner has been considered by Vietnamese policymakers as crucial for the continued integration of Vietnam into the world economy and thus for sustaining the country's rapid economic growth. In this context, Vietnam's participation in the TPP can be viewed as "the second opening for the country" in that the TPP represents a state-of-the-art FTA for the twenty-first century. The TPP may be an opportunity as well as a challenge for Vietnam as a developing country, and now the key issue in the TPP is what needs to be done by Vietnam to seize opportunities and tackle challenges.

It is clear that Vietnam can achieve huge economic gains from the TPP, but the country needs to negotiate sensitive issues in an effective manner from the perspective of the national economy. This paper tries to assess major issues of Vietnam's joining the TPP, and to draw policy implications such as initiativesfor Vietnam's acceleration of its renovation and economic restructuring programs; and domestic measures for facilitating FTA implementation by firms and enhancing the country's implementation capacity. 


\section{Initial (Target) Structure of the TPP}

According to a statement by the leaders of the TPP member countries in October 2013 in Brunei, "we have agreed that negotiators should now proceed to resolve all outstanding issues with the objective of completing this year a comprehensive and balanced, regional agreement that achieves the goals we established in Honolulu in 2011, ensures the benefits of the agreement are fully shared, and takes into account the diversity of our levels of development."

This section summarizes the broad outline of the ambitious TPP reported to the TPP leaders at the 2011 APEC Leaders' Meeting (Honolulu, Hawaii). This can be said to be the goal that would be pursued by the TPP member countries. The initial structure of the TPP was generally considered to be designed by the U.S., reflecting the position of developed countries, and therefore it can be a source of conflict in the negotiations, that is, barriers to concluding the TPP. Some of those barriers include the internal U.S. division on central issues and the substantive disagreement among the key countries on factors associated with sanitary and phytosanitary standards (SPS), technical barriers to trade (TBT), the protection of intellectual property rights (IPR), investor-state dispute settlement (ISD), labor and environmental regulation, government procurement (GP), rules of origin, regulation on state-owned enterprises (SOEs), and pharmaceutical issues. More than 20 negotiating groups have met to develop the initial structure of the agreement and the principles of the specific market access commitment to be made by the TPP countries to open their markets to one another's goods, services, and government procurement.

The TPP is an initiative to establish a regional FTA in the Asia-Pacific region. A total of 21 working groups have been negotiating 29 chapters of the TPP. Because TPP negotiators aim for a comprehensive FTA for the twenty-first century, it is not easy to conclude the negotiations for a high-quality FTA satisfying the interests of both developing and developed countries. Therefore, the TPP has progressed gradually, and competing interests and complex structural issues may slow or stall its negotiations. In contrast to the statement by the leaders, negotiators face substantial hurdles in reaching an agreeing on the need to appropriately address sensitivities of and distinct challenges faced by developing countries, including trade capacity building, technical assistance, and the staging of some commitment as necessary. Although all of the nine TPP countries at the Honolulu meeting stated that they agreed to adopt high standards to ensure that benefits and obligations of the agreement would be fully shared, ${ }^{1)}$ it is known that there are many issues remain unsolved and that the current quality of the TPP (based on known information) is far below the

1) At this time, nine countries were participating in the TPP negotiation. 
original goal. Section 4 discusses the sensitive issues and current status of the TPP negotiations, and based on this, section 5 tries to describe the structure of the TPP agreement.

In reporting to the leaders on the achievement of the broad agreement outline, the trade ministers identified five defining features that would make the TPP a landmark trade agreement for the twenty-first century, setting a new standard for global trade and incorporating next-generation issues that would boost the competitiveness of the TPP countries in the global economy. The broad framework of the TPP can be summarized as follows:

- Comprehensive market access: Eliminate tariffs and other barriers to trade in goods and services and investment to create new opportunities for workers and firms and generate immediate benefits for consumers.

- Fully regional agreement: Facilitate the development of production and supply chains for the TPP members, supporting the goal of creating jobs, raising living standards, improving welfare, and promoting sustainable growth.

- Cross-cutting trade issues: Works and agreements being done by APEC and other related organizations by incorporating the TPP.

- New trade challenges: Promoting trade and investment in innovative products and services, including those related to the digital economy and green technologies, and ensure a competitive business environment across the TPP region.

- Living agreement: Enabling the updating of the agreement as appropriate to address trade issues that may emerge in the future as well as new issues that may arise with the expansion of the agreement to include new countries.

\section{Table 1.}

The Initial (Target) Structure of the TPP

\begin{tabular}{l|c|l}
\hline \multirow{2}{*}{ Market Access } & $\begin{array}{c}\text { Goods } \\
\text { Apparel }\end{array}$ & $\begin{array}{l}\text { Elimination of tariffs. The TPP tariff schedule will cover all } \\
\text { goods, representing some 11,000 tariff lines }\end{array}$ \\
\cline { 2 - 3 } & $\begin{array}{l}\text { A series of related disciplines, such as customs cooperation and } \\
\text { enforcement procedures, rules of origin and a special safeguard }\end{array}$ \\
\hline $\begin{array}{l}\text { NTBs and } \\
\text { agriculture }\end{array}$ & $\begin{array}{l}\text { The TPP partners are considering proposals related to import and } \\
\text { export licensing and remanufactured goods. Additional provisions } \\
\text { related to agricultural export competition and food security also } \\
\text { are under discussion. }\end{array}$ \\
\hline
\end{tabular}




\begin{tabular}{|c|c|c|}
\hline & Services & $\begin{array}{l}\text { Elimination of barriers. Services and investment packages will } \\
\text { cover all service sectors, negotiating on a "negative list" basis, } \\
\text { which presumes comprehensive coverage but allows countries to } \\
\text { negotiate specific exceptions to commitments in specific service } \\
\text { sectors. }\end{array}$ \\
\hline Investment & & $\begin{array}{l}\text { Provide substantive legal protections for investors and investments } \\
\text { of each TPP country in the other TPP countries, including ongoing } \\
\text { negotiations on provisions to ensure non-discrimination, a } \\
\text { minimum standard of treatment, rules on expropriation, and } \\
\text { prohibitions on specified performance requirements that distort } \\
\text { trade and investment }\end{array}$ \\
\hline \multirow{5}{*}{ Trade Rule } & Customs & $\begin{array}{l}\text { Establishing customs procedures that are predictable, transparent } \\
\text { and that expedite and facilitate trade }\end{array}$ \\
\hline & Rules of Origin & $\begin{array}{l}\text { Rules of origin will be objective, transparent and predictable and } \\
\text { are discussing approaches regarding the ability to cumulate or use } \\
\text { materials from within the free trade area in order to make a claim } \\
\text { that a product is originating. A system for verification of } \\
\text { preference claims that is simple, efficient and effective. }\end{array}$ \\
\hline & Trade Remedies & $\begin{array}{l}\text { Affirming the WTO rights and obligations, and proposals for a } \\
\text { transitional regional safeguard mechanism }\end{array}$ \\
\hline & $\begin{array}{c}\text { Sanitary and } \\
\text { Phytosanitary } \\
\text { Standards (SPS) }\end{array}$ & $\begin{array}{l}\text { Reinforce and build upon existing rights and obligations under the } \\
\text { World Trade Organization Agreement on the Application of } \\
\text { Sanitary and Phytosanitary Measures }\end{array}$ \\
\hline & $\begin{array}{l}\text { Technical } \\
\text { Barriers to } \\
\text { Trade (TBT) }\end{array}$ & $\begin{array}{l}\text { Facilitate trade among the TPP countries and help our regulators } \\
\text { protect health, safety, and the environment and achieve other } \\
\text { legitimate policy objectives }\end{array}$ \\
\hline \multirow[t]{3}{*}{ New Issues } & Labor & $\begin{array}{l}\text { A labor chapter that includes commitments on labor rights } \\
\text { protection and mechanisms to ensure cooperation, coordination, } \\
\text { and dialogue on labor issues of mutual concern. They agree on the } \\
\text { importance of coordination to address the challenges of the } \\
\text { 21st-century workforce through bilateral and regional cooperation } \\
\text { on workplace practices to enhance workers' well-being and } \\
\text { employability, and to promote human capital development and } \\
\text { high-performance workplaces }\end{array}$ \\
\hline & Environment & $\begin{array}{l}\text { Include effective provisions on trade-related issues that would } \\
\text { help to reinforce environmental protection and are discussing an } \\
\text { effective institutional arrangement to oversee implementation and } \\
\text { a specific cooperation framework for addressing capacity building } \\
\text { needs. }\end{array}$ \\
\hline & E-Commerce & $\begin{array}{l}\text { Provisions addressing customs duties in the digital environment, } \\
\text { authentication of electronic transactions, and consumer protection }\end{array}$ \\
\hline
\end{tabular}


Table 1 can be grouped by tasks for 21 working groups for the easy identification of major negotiation issues, although each can be analyzed in detail. These 21 areas reflect the most important issues included in most comprehensive FTAs. Because 12 countries currently participate in the TPP negotiations, the depth and coverage of these issues vary according to the member country, although all these areas are considered for their incorporation into the final agreement. Therefore, the quality of the TPP should be assessed by just checking how many of these are incorporated into the final agreement. All countries, even the U.S., will face domestic problems over some of these traditional and new issues, since the structure of the initial TPP was designed by the U.S. trade authority. In case of the U.S., the Congress raises objections over the agreement made by the trade authority. It is clear that a country-specific assessment of each area is more important than the whole structure of an agreement, since the allowance of substantial exceptions will be given to some members, deteriorating the quality of the agreement.

\section{Issues of TPP negotiation for Vietnam}

\subsection{Tariffs}

Traditionally, tariffs have been the core of economic gains in any FTA. Therefore, the economy usually takes a majority of the weight during negotiations. It is generally known that FTA negotiations are conducted with some economic analysis at the core. Tariffs become a type of primary indicator for FTA members not only because they can be analyzed quantitatively but also because they are relatively easy for participants to cross-correlate. Tariffs are closely related to other areas of the FTA such that they ultimately determine how inclusive or open it is, and therefore there is a tendency for the whole structure to be designed and built toward the end of the negotiation process.

Vietnam implemented FTAs with ASEAN members, Japan, Australia and New Zealand out of the TPP member countries. Since the TPP adopts the tariff schedules of currently existing FTAs, Vietnam needs to conclude bilateral negotiations for tariff liberalization with the US, Canada, Mexico, Peru and Chile.

It will not easy for Vietnam to negotiate the market access for goods, since the country has liberalized its goods market following the practice of the ASEAN+1 FTAs. For example, in the Trade in Goods (TIG) Agreement in the framework of the ASEAN-KOREA Free Trade Agreement (AKFTA), ${ }^{2}$ ) the liberalization of trade in merchandise will be pursued in two tracks, namely the Normal Track (NT) and Sensitive 
Track (ST). The ST, which includes the remaining goods in the import tariff nomenclature of each country, is divided into two lists, the Sensitive List (SL) and Highly Sensitive List (HSL).In terms of NT, Viet Nam committed to reduce and completely remove almost all tariff lines under NT by 2016, 6 years later than the ASEAN 6, with some tariff lines having the deadline flexibly extended until 2018. Meanwhile, Korea eliminated all its tariffs for tariff lines placed in NT by 2010.In terms of SL, Viet Nam committed to reduce all SL tariff rates to $20 \%$ not later than by 2017 and subsequently $0-5 \%$ not later than by 2021 . As for Korea (and the ASEAN 6), the schedule is shorter, with the deadlines being 2012 and 2016 respectively.

Basically, the members of ASEAN+1 FTAs decide two tracks and two lists with relevant shares out of the total number of tariff lines (or combined with trade shares) first, and then they are allowed to classify sectors into tracks and lists. However, this is not a way to FTAs for developed countries, whose negotiations are done with the "Request/Offer" (RO). The RO approach requires a lot of information on industrial competitiveness and close linkages with the business sector, which are much easier to obtain for developed countries.

As shown in Figure 1, Vietnam's average tariff rates have decreased sharply relative to the MFN rate (13.4\% as of 2013). However, the country has allocated many sectors of goods to sensitive tracks, and therefore tariffs are not likely to be completely eliminated in its FTAs even by 2023. In terms of average tariffs in its FTAs with China, Japan, and Korea, Vietnam has agreed to differential tariff schedules. Among the three FTAs, the ASEAN-Japan FTA has a very slow tariff liberalization schedule. Although it is unclear whether Japan has attempted to improve the existing tariff schedule, the same tariff offers may not be acceptable for the U.S., which is likely to be aggressive in opening its market for exporting goods. However, in order to conclude the negotiations and to increase the access for the U.S. market, Vietnam needs to offer its market opening to the U.S.

2) The agreement was signed in August 2006 and took effect on 1st June 2007. 


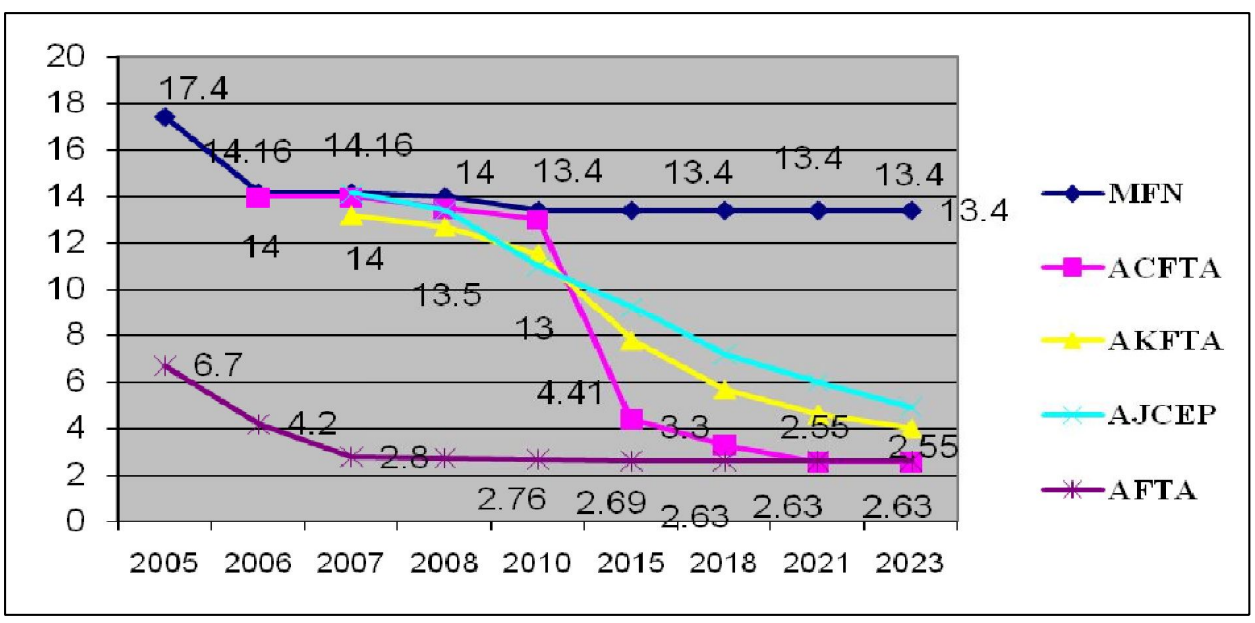

Figure 1.

Vietnam's tariff cut schedules under the WTO and various FTAs

Source: Phạm Chi Lan(2013) "NHİN LẠI 5 NĂM VIỆT NAM GIA NHẬP WTO: Nhữngthànhtựuvàhạnchế"

Along with tariff liberalization, the efficiency of customs clearance is crucial for expanding intra-member trade. Non-tariff barriers in the U.S. are generally low, but after the 911 terrorist attacks, the U.S. implemented the CSI (Container Security Initiative), which has slowed the customs process. Here similar initiatives may be implemented in the future, dramatically slowing the import/export process and ultimately increasing distribution costs. To expedite and smooth the process of trade between parties, each must either adopt or maintain an effective customs clearance procedure and consider a system that allows for the transport of goods within 48 hours of arrival, as in the case of the KORUS FTA, to expedite the transport of goods. In addition, all information on goods needs to be submitted and processed electronically. To expedite and automate customs clearance procedures, involved parties must develop a compatible electronic system and adopt or maintain an automated risk management system. To smooth the trade system for both parties, each must improve its risk management system, smooth its international distribution network standards, simplify procedures for efficient and timely trade, improve employee skills, and provide technical support and consultation to the other party to enhance applied technologies. A pre-evaluation system should be allowed. That is, a member must issue a pre-evaluation report within 90 days after its customs officials submit a request, and the requester must submit a copy of all information, including samples of goods, requested by the partner. 


\subsection{Rules of Origin ${ }^{3}$}

Market access in an FTA should be evaluated from several viewpoints, that is, tariff elimination, easing of non-tariff barriers (NTBs) such as customs clearance, simplicity of the ROO, improvement of trade rules, and so on. While some of these criteria, such as harmonization of trade rules, cannot be easily measured quantitatively, the coverage of the tariff elimination and the simplicity of the ROO can be quantitatively measured. Generally, it can be said that FTAs with extensive tariff elimination coverage and a simple (less stringent) ROO will bring about the most economic gains upon their conclusion. Although FTAs specify tariff elimination for all goods, their net impact on trade will be reduced if exporters (manufacturers) are obliged to pay high costs to comply with complex and stringent ROOs in the FTAs. If a low tariff is included in the list of trade liberalization measures and a stringent ROO is applied, only limited impacts on trade can be expected.

Table 2.

Effects of Tariff Elimination and ROOs on Trade

\begin{tabular}{c|c|c|c}
\hline \multirow{2}{*}{} & \multicolumn{2}{c}{ Stringency of ROO } \\
\cline { 3 - 4 } \multicolumn{2}{c|}{} & Less & More \\
\hline \multirow{2}{*}{ Coverage of tariff elimination } & Wide & High impact & Low impact \\
\cline { 2 - 4 } & Narrow & Low impact & Limited impact \\
\hline
\end{tabular}

Source: Cheong (2008) "Importance of Market Access in Paving the Way towards anEast Asian FTA", Journal of Korea Trade, December

Traditionally, two types of preferential ROOs can be found in FTAs: European type and NAFTA type. These rules are highly complicated and designed for the purpose of trade protectionism in several sectors such as automobiles and textiles. However, an Asian version has emerged in the last decade since the conclusion of ASEAN+1 FTAs. The third type is relatively simple and harmonized across FTAs, although numerous types of ROOs are used with large variations such as combinations of rules, co-equal or "plus" rules, specific production rule (SPR), regional value contents (RVC), and variations in change in tariff classification (CTC). The rule most commonly used is RVC (40) except for the ASEAN-India FTA (AIFTA), which uses RVC (35) + CTSH(CTC at the six-digit tariff classification). The ASEAN Trade in Goods Agreement (ATIGA) has the most liberal rule, with the RVC of at least $40 \%$ of CTH (CTC at the four-digit tariff classification).

3) This section is heavily depends on Cheong (2008) "Importance of Market Access in Paving the Way towards anEast Asian FTA", Journal of Korea Trade, December 
Table 3.

ROOs in the ASEAN+1 FTAs

\begin{tabular}{|c|c|c|}
\hline Agreements & Methods of Determining Origin & General Rule \\
\hline \multirow{4}{*}{$\begin{array}{l}\text { ASEAN Trade in } \\
\text { Goods Agreement } \\
\text { (ATIGA) }\end{array}$} & 1. Wholly obtained (or produced) (WO) & RVC (40): RVC of at least $40 \%$ or \\
\hline & 2. Regional Value content (RVC) & CTH: CTC at 4 digit \\
\hline & 3. Change in tariff classification (CTC) & \\
\hline & 4. Specific process rule (SPR) & \\
\hline \multirow{3}{*}{$\begin{array}{l}\text { ASEAN--PRC Trade } \\
\text { in Goods Agreement }\end{array}$} & 1. WO & RVC (40) \\
\hline & 2. RVC & \\
\hline & 3. SPR & \\
\hline \multirow{4}{*}{$\begin{array}{l}\text { ASEAN--Korea Trade } \\
\text { in Goods Agreement }\end{array}$} & 1. WO & $\begin{array}{l}\text { RVC (40) or CTH (Change in } \\
\text { Tariff Heading) }\end{array}$ \\
\hline & 2. RVC & \\
\hline & 3. CTC & \\
\hline & 4. SPR & \\
\hline \multirow{4}{*}{$\begin{array}{c}\text { ASEAN-Japan } \\
\text { Comprehensive } \\
\text { Economic Partnership } \\
\text { (AJCEP) }\end{array}$} & 1. WO & RVC (40) or CTH \\
\hline & 2. RVC & \\
\hline & 3. CTC & \\
\hline & 4. SPR & \\
\hline \multirow{4}{*}{$\begin{array}{c}\text { ASEAN-Australia/Ne } \\
\text { w Zealand } \\
\text { (AANZFTA) }\end{array}$} & 1. WO & RVC (40) or CTH \\
\hline & 2. RVC & \\
\hline & 3. СTC & \\
\hline & 4. SPR & \\
\hline \multirow[t]{2}{*}{$\begin{array}{l}\text { ASEAN--India Trade } \\
\text { in Goods Agreement }\end{array}$} & 1. WO & $\begin{array}{l}35 \% \text { RVC }+ \text { CTSH (Change in } \\
\text { Tariff Subheading) }\end{array}$ \\
\hline & 2. $35 \% \mathrm{RVC}+\mathrm{CTSH}$ & \\
\hline
\end{tabular}

Source: Medalla and Rosellon(2011)

A key issue of TPP ROO for Vietnam is the fiber rule on textile and clothing (TC), along with other factors. Considering strong limitations in expanding the production of fiber in Vietnam, the rule will undermine substantial portion of expected gains from the TPP. However, it is not likely that the U.S. adopts different types of the ROO on TC. Similar case happened in the negotiation of the KORUS FTA.

Also a supplementary rule such as De Minimis is allowed in the paragraph 7 of CHAPTER FOUR (Textiles and Apparel). "A textile or apparel good that is not an originating good because certain fibers or yarns used in the production of the component of the good that determines the tariff classification of the good do not undergo an applicable change in tariff classification set out in Annex 4-A shall nonetheless be considered to be an 
originating good if the total weight of all such fibers or yarns in that component is not more than seven percent of the total weight of that component. Notwithstanding the preceding sentence, a good containing elastomeric yarns in the component of the good that determines the tariff classification of the good shall be considered to be an originating good only if such yarns are wholly formed and finished in the territory of a Party."'4),5)

\subsection{Non-tariff barriers}

FTAs target improvements in trade rules for developing countries in the context of trade facilitation. Various non-tariff barriers are identified and requested for their elimination or improvement. For labor and environmental issues, the TPP members are expected to agree on checking and efficiently carrying out their duties to uphold internationally acknowledged labor and environmental rights. Negotiation results concerning labor and environment areas are expected to be set to a level reflecting domestic practices and regulations but not nearly to that at which domestic firms bear heavy burdens.

Each member commits not to apply or maintain a ban or any quantitative restriction on the importation of any goods from other members or on the exportation of any goods to the territory of other members unless otherwise specified in accordance with rights and obligations under the WTO regulations or with other TPP terms. Each member ensures the transparency of their non-tariff measures such that they are not prepared, adopted or applied to create unnecessary barriers to trade between the TPP members.

\subsection{SPS and TBTconditions}

In many FTAs, regulations on SPS and TBT in form of "the WTO plus"can become hot issues for some sectors such as food and automobiles, since these issues are closely related to the enforcement of domestic rules and related transparency. Given the importance of improving business environments, the establishment of strong enforcement and transparency can be evaluated positively.

4) For purposes of paragraph 7 , wholly formed and finished means all production processes and finishing operations, beginning with the extrusion of filaments, strips, film, or sheet, and including drawing to fully orient a filament or slitting a film or sheet into strip, or the spinning of all fibers into yarn, or both, and ending with a finished yarn or plied yarn.

5) For purposes of paragraph 7, wholly formed and finished means all production processes and finishing operations, beginning with the extrusion of filaments, strips, film, or sheet, and including drawing to fully orient a filament or slitting a film or sheet into strip, or the spinning of all fibers into yarn, or both, and ending with a finished yarn or plied yarn. 
The TPP members have acknowledged the importance of transparency in TBT and SPS regulations, as specified in the TBT and SPS Agreements of the WTO, which include notification procedures for the preparation of TBT/SPS regulations and standards to minimize adverse impacts on trade as well as to protect human, animal, and plant life and health. The members have agreed to establish the TBT/SPS Working Group under the Implementation Committee to address issues surrounding their implementation, facilitate trade, and protect human, animal, and plant life and health through joint cooperation and bilateral consultation. The Working Group on TBT and SPS regulations consists of government officials from agencies responsible for agriculture, fisheries, livestock, industries, and other relevant sectors. The Working Group has built its own working programs and met at least once a year or by mutual arrangement.

\subsection{State-owned enterprises(SOEs)}

With the characteristics of the Socialist political system, Vietnam has a large public sector and supports SOEs as part of its industrial policy. According to Trang (2012), the public sector accounts for the largest share of its total investment, followed by the private and foreign sectors: "State-owned companies use up about 50 percent of state investment, tie up 60 percent of bank lending and account for more than half of the nation's bad debt, according to Deputy Finance Minister Truong Chi Trung. Restructuring the state sector is one of the 'most crucial and urgent tasks' to reform the economy."')

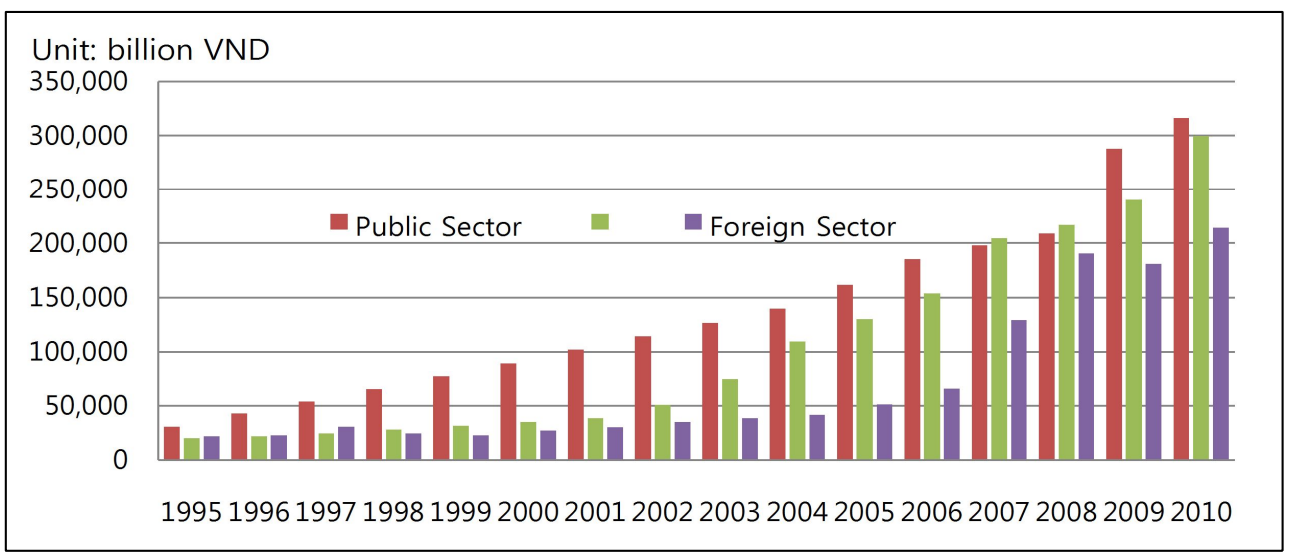

Figure 2.

Investments by sector in Vietnam (1995 - 2010)

6) Bloomberg News (2013) “Vietnam Gets Tough on State Firms in Economic Growth Push”July 25, 2013 
Vietnamese groups and SOEs were established by the decision of the prime minister in 1990 and 1991 as a key pillar of Vietnam's efforts to become an industrial country by 2020 . SOEs (11 groups and 85 SOEs as of 2011) have been responsible for investing in the country's infrastructure and technology but have faced a lack of quality labor and managers, and the government has protected them from competition from MNCs. The government budget has been provided through loans at low interest rates (not officially announced). Lower corporate tax rates and the prioritization of these entities over private firms in participating government projects, in addition to easy access to state funds and real estate and even lower electricity and water charges, have these firms. In general, there is a lack of regulation or a legal framework for SOEs, which account for 34\% of GDP (2010).7) With government support, most SOEs have been profitable, but some groups have faced large losses. ${ }^{8)}$

China's experience may provide Vietnam with a good reference. China has implemented various industrial reforms for its SOEs since the late 1990s, and the number of SOEs declined from 64,737 in 1998 to 17,052 in 2011. With these reforms, average profitability has improved, and many of its SOEs have become global corporations, although some still depend on government subsidies. Although the number of SOEs has decreased, their output relative to that of private firms has increased sharply. The average revenue of SOEs from product sales was 6 times that of private firms listed on the Beijing stock exchange as of 2004, rising to 11 times in 2011.

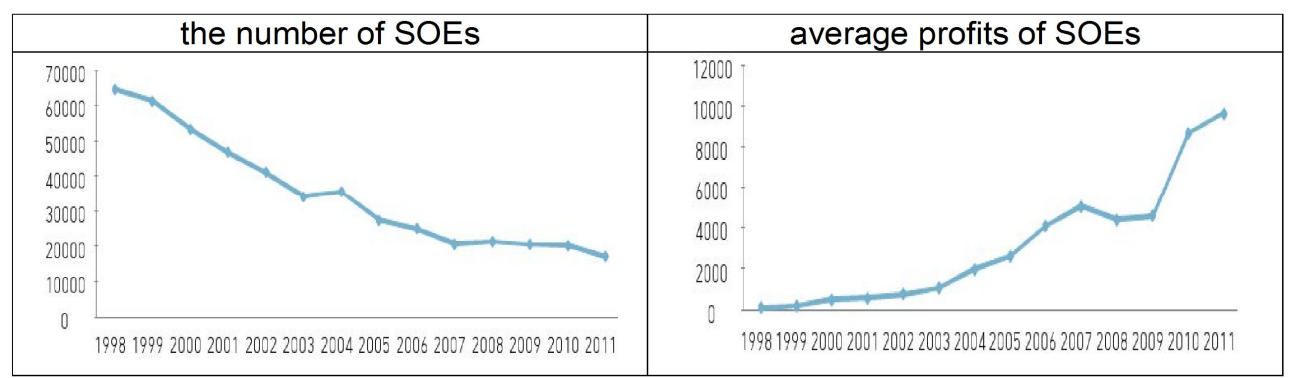

Figure 3.

The trend of the number of SOEs in China

Source: Ko, Jongo and Jungran Cho (2013), "China's nonmetallic industry and implications for the Korea-China FTA" forthcoming in the Journal of International Logistics and Trade

7) Le Thu Trang (2012) “State owned enterprises in Vietnam”, Policy Design and Implement in Developing Countries

8) EVN(Vietnam Electricity) had a loss of VND 24,000 billion ( $\$ 1.2$ billion) as of 2011, and Vinashin, VND 5,000 billion (\$250 million). Vinashin declared bankruptcy in 2012. Only four groups (Petro Vietnam, VNPT, Viettel, and Vietnam Rubber Group) accounted for $80 \%$ of all profits from groups and SOEs. 
In terms of economic reform, SOE regulation and measures for improving efficiency should be explored in the context of the TPP negotiations. An independent supervisory agency, investment transparency, financial performance and management, and improved equality between the public and private sectors are needed for Vietnam's economy. Bloomberg News (2013) reported that "Vietnam Gets Tough on State Firms in Economic Growth Push." Vietnam plans tougher rules to accelerate its revamp of SOEs, including firing chief executives, making more effort to clear bad debt in the banking industry, and reviving the economy. The finance ministry is drafting "strong and suitable" measures to force SOEs to sell stakes in non-core businesses, and an asset management firm run by the central bank has started in July 2013 to help clear almost \$5 billion in bad debt. Matt Hildebrandt, a Singapore-based economist at JPMorgan Chase \& Co., stated that "SOEs and banks are large parts of the economy, so if you don't make them more efficient and stronger, the economy will not grow as quickly" and that "Even in a really well-implemented bank recapitalization plan, it would always take some time. Fixing SOEs or deleveraging them will be a multi-year, maybe decades-long process."

\subsection{Protecting intellectual property rights}

It is undeniable that intangible assets such as technology and knowledge are increasingly becoming influential factors in determining a country's place in terms of global competition. An economic transformation into a knowledge-based economy is in rapid progress, and many developed countries such as the U.S. and Japan generate more than $50 \%$ of their total value added from knowledge. As futurologist Peter Drucker suggested, the twenty-first century is expected to be composed of knowledge-based societies in which knowledge and information are core elements of personal and national competitiveness.

To prepare for its accession to the WTO (January 2007), Vietnam adopted principal international IPR institutions and agreements, including the Berne Convention (copyrights) in 2004, the Madrid Protocol (trademarks) in 2006, the Paris Convention (priority rights) in 1949, the Patent Cooperation Treaty (patents) in 1993, and the WTO/TRIPS (IPRs in general) in 2007. However, it is not a signatory to theHague Agreement/Geneva Act (designs). In Vietnam, the regulatory system for protecting IPRs was first established in 2005, when the country joined the WTO through the Law on Intellectual Property. Over the years, however, inherent deficiencies and administrative loopholes have severely undermined the efficacy of the system and made it difficult for both IPR owners and authorities to take action on infringers.9)

9) Hunter Rodwell Consulting (2013) "Intellectual Property Rights Primer for Vietnam: A Guide for UK 
In general Vietnam's IPR legislation is comprehensive, covering every aspect of theprotection of intellectual property in accordance with the international standardsrequired by the WTO rule of the TRIPS. The regulations have been thoroughlyrewritten in recent years to conform withthe guidelines of TRIPS, resulting in the new IP law thatcame into force in 2006. This brought together and tidied up the various codes,decrees, circulars and internal regulations from the National Office of IntellectualProperty (NOIP) and the National Copyright Office (NCO), which were sometimesconflicting and hard for rights owners to understand. A series of implementingdecrees and circulars has subsequently been promulgated to clarify the principlesof the IP Law.

However the enforcement agencies have found it difficult to keep up with theserapid changes: administrative enforcement is complicated by the large number ofbodies involved, while the training of court officials handling IP cases remainsdeficient. Apart from implementing its WTO commitments, Vietnam must nowbring its IP system fully into line with the TRIPS and other internationalconventions. Infringement is widespread and becoming more and more complex. The mechanisms and organs for enforcement are still under development andthere remain some problems with the law which have yet to be ironed out. Forexample, the IP-related aspects of the Competition Law (see below) are largelyuntested. ${ }^{10)}$

In January 2013, the Vietnamese Government issued a Decree (No: 08/2013/ND-CP) (the Decree) to further cut down on red tape and make it easier to initiate action against counterfeiters. This Decree is in addition to the previous Decree No: 97/2010, which applies to administrative violations in IP. The issuance of these Decrees, together with other steps taken by the Vietnamese Government to curb IP violations, is a clear indicator of the Government's intention to improve the robustness of IP rights in Vietnam. Further, to avoid Vietnam being used as a base for in-transit counterfeit goods, there are also provisions for forcible expulsion and re-export of infringing goods from Vietnamese territory. One of the most important aspects of the Decree is that it recognizes counterfeiting of certain essential products, namely, foods, medicines, fertilizers, food additives, breeds of plants and animals, animal feed, veterinary medicines, pesticides, cosmetics, medical equipment, cement, building steel and helmets, as a very serious offence for which the penalty can extend up to D70,000,000 (around US\$3,500). Additional forms of penalties include confiscation of the exhibits and instruments for committing violations and temporary or indefinite revocation of the practice certificate or license of entities engaged in counterfeiting activities. ${ }^{11)}$

Companies," http://www.ipo.gov.uk/ipr-guide-vietnam.pdf.

10) http://www.mirandah.com/ja/pressroom/item/379-ip-protection-in-vietnam-government- tightensenforcement-against-counterfeiting 
In many aspects, Korea has yielded to the U.S. in the area of IPR negotiation, implying that the U.S. will be aggressive in dealing the issues of IPR in the TPP negotiation. The fact that the copyright protection period has been extended from 50 years to 70 years after the death of the author reflects the U.S. demands, but rationalized patent examinations, trademark protection, and other IPR-related policies can be ways for Korea to strengthen its global competiveness. This is expected to expand the value added of Korean IPRs, as suggested by the Korean wave and other developments. It has also established the grounds for Korea to request IPR protection from China and other Southeast Asian counties that increasingly violate Korean IPRs.

\section{Conclusion and Implications for Vietnam}

Since Vietnam's launch of "DoiMoi" (the all-round renovation process) in 1986, the country started to embrace general development and the process of gradual globalization and regionalization. With the renovation process, Vietnam has gradually addressed many difficulties and hindrances and achieved impressive results. During the 1991-1998 periods, the average GDP growth rate reached 8\%. In 1999, the economy was seriously affected by the economic crisis in the region and natural calamities, and therefore its GDP grew by only $4.5 \%$. However, economic performance was inspiring in 2000, showing a $6.7 \%$ GDP growth rate in the first nine months. By September 2000, FDI reached $\$ 36$ billion based on 2,500 projects; inflation decreased from $67.1 \%$ (in 1991) to $6 \%$ (in 2000); and living standards improved for a majority of Vietnamese citizens. Cultural and intellectual standards continued to increase, and in general, the country has made much progress in the fields of education, health care, culture and art, sports, family planning, public media, and other social activities. ${ }^{12)}$

Vietnam needs to keep in mind that competingcountries can quickly catch up. China has a rapidly aging population and thus is likely to lose its advantage in labor supply in future. The demographics of Vietnam look similar to those of China in the early 1990s, when its export manufacturing sector started to boom on the back of cheap labor. Vietnam ranks third after China and Thailand in terms of the average age, and therefore, Vietnam is expected to follow the pattern of an aging population, resulting in sudden and serious

11) Hunter Rodwell Consulting (2013) "Intellectual Property Rights Primer for Vietnam: A Guide for UK Companies", http://www.ipo.gov.uk/ipr-guide-vietnam.pdf

12) Embassy of Vietnam in South Africa (2013) "Economic renovation: DoiMoi", viewed at http://www.vietnam.co.za/index.php?option=com_content\&view=article\&id=114:economic-renovationdoi-moi\&catid=45:history-of-vietnam\&Itemid $=1 \overline{14}$ 
shortages of labor needed to meet current and future production requirements. In addition, wage ratesare likely to increase, weakening the country's global competitiveness relative to less developed countries such as Cambodia, Bangladesh, and Pakistan. ${ }^{13)}$

\section{Table 4.}

Average ages of selective developing countries in Asia

\begin{tabular}{c|c}
\hline Country & Years \\
\hline Pakistan & 21 \\
\hline Cambodia & 22 \\
\hline Philippines & 23 \\
\hline Bangladesh & 25 \\
\hline India & 25 \\
\hline Malaysia & 26 \\
\hline Indonesia & 28 \\
\hline Vietnam & 29 \\
\hline Sri Lanka & 31 \\
\hline Thailand & 33 \\
\hline China & 34 \\
\hline
\end{tabular}

Source: KPMG International (2011) "Product Sourcing in Asia Pacific New locations, extended value chains", viewed at www.kpmg.com

As discussed in the previous section, the economic effects of the TPP are likely to vary according to the content of the agreement. Because Vietnam is one of the least developed countries among the TPP members, the country has a great potential for improving its economic system (or economic reform) for large economic gains, although it is likely to face large economic and political burdensfrom the structural adjustment. Although it remains unclear, the TPP may force improvementsin the transparency of domestic practices. Although a more transparent economic and bureaucratic system is needed for Vietnam, it is not easy to change traditional practices. However, Vietnam should take advantage of the TPP for its economic reform. The share of manufacturing as the percentage of GDP in selected Asian countries ranges from 16\% (India) to 34\% (China). For Vietnam, it is $20 \%$, which is much lower than that of competing neighboring ASEAN countries, including Malaysia (25\%), Indonesia (27\%), and Thailand (34\%). In this regard, KPMG (2011) asserted that Vietnam manufacturing sector has a large capacity to grow.

13) KPMG International (2011) "Product Sourcing in Asia Pacific New locations, extended value chains" www.kpmg.com 


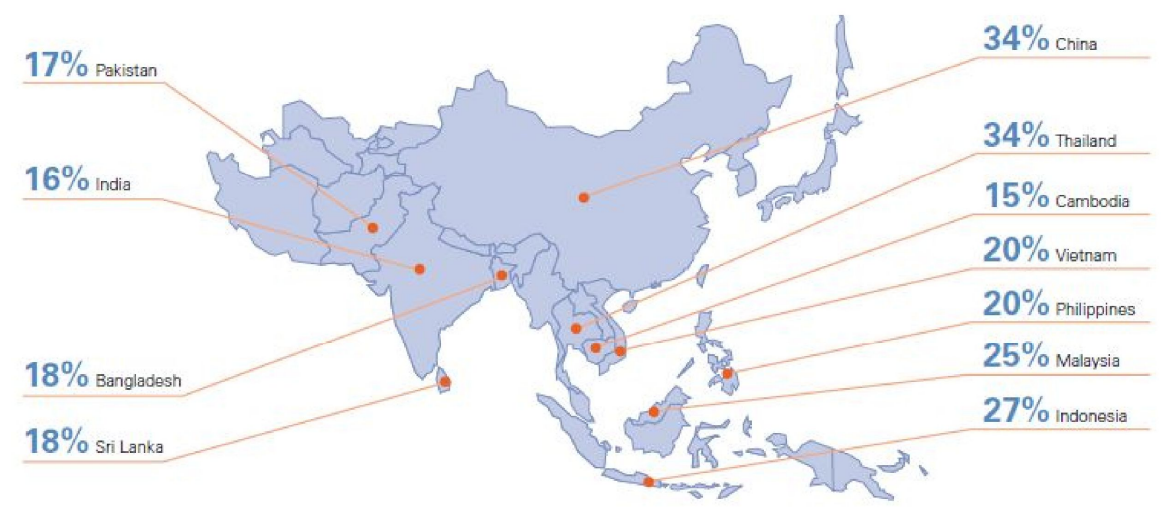

Figure 4.

Asian countries' capacity to grow

(Unit: Manufacturing as \% of GDP in selected Asian countries)

Source: KPMG International (2011) "Product Sourcing in Asia Pacific New locations, extended value chains", viewed at www.kpmg.com

Lan(2013), a Vietnamese economist, found large fluctuations in economic performance from economic crises (the East Asian crisis in 1997-1999 and the global financial crisis in 2008-2009) and the rapid deterioration of the macroeconomic indicator since 2010 immediately after recovery from the global financial crisis. She forecasted Vietnam's GDP growth rate in 2013 to be $4.9 \%$, a rate almost as low as that during the East Asian crisis (4.8\%). A more serious issue is that the three-year moving average of the annual GDP growth rate has declined since 2005, implying the weakening of Vietnam's economic growth potential over time.

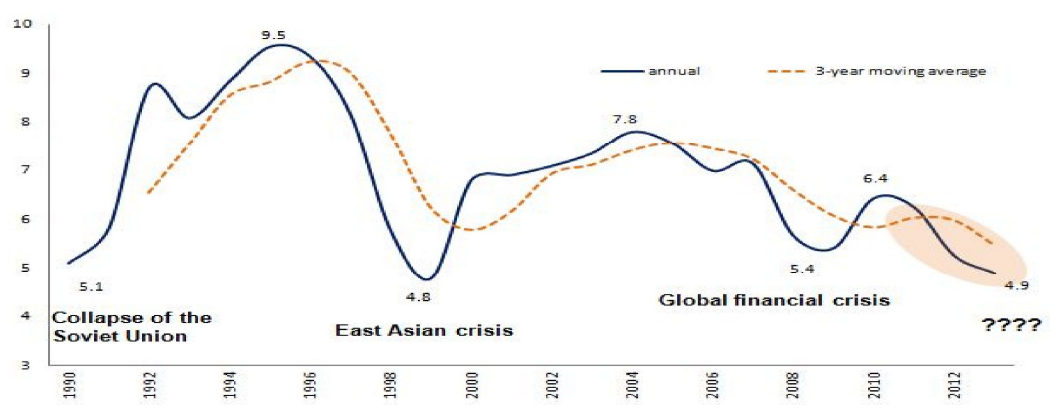

Figure 5.

Trend of Vietnam's GDP (\%)

Source: Phạm Chi Lan(2013) 'NHİN LẠI 5 NĂM VIỆT NAM GIA NHẬP WTO: Nhữngthànhtựuvàhạnchế" 
One of the key issues in slowing the potential of Vietnam's economic growth can be found in the stagnation of the inflow of FDI into the country. Although there is some limitation in the growth of world FDI because of the economic (financial and fiscal) crisis, Vietnam has some advantage in attracting FDI from multinational companies (MNCs) because many MNCs are planning to leave China because of wage hikes and new environmental regulations and MNCs are looking for alternative investment destinations. However, Vietnam's ratio of FDI to GDP decreased from 12\% in 2008 to $10 \%$ in 2010 and further down to $7 \%$ in 2012 .

The decreases in FDI into Vietnam and slowing GDP growth are in direct contrast to the case of China. In the third quarter of 2013, China's GDP growth rate was $7.8 \%$, a $0.3 \% \mathrm{p}$ increase from the second quarter. Several economic indicators indicate this to be a genuine economic rebound in economic activity. Sustainable drivers of GDP such as economic reform in various sectors, manufacturing investment, and exports to developed economies drove the rebound and bullish economic sentiments. KPMG's (2013) China Economy Globalization Review expects the impact of reform dividends to increase the potential economic growth rate.

Finally, Vietnam should take advantage of the TPP initiative as its catalyst for its renovation, facilitating economic restructuring, and transforming itseconomic structure. The country should not view the TPP just for the export of textiles to the US, but very precious chance for improving its business environment which is a key requirement in inducing the inflow of foreign direct investment. 


\section{References}

Armstrong, Shiro. 2011. China's participation in the Trans-Pacific Partnership. East Asia Forum, Viewed on December 11, http://www.eastasiaforum.org/2011/12/11/chinaparticipation -in-the- trans-pacific-partnership/.

Baier, Scott L. and Jeffrey H.Bergstrand. 2006. Economic Determinants of Free Trade Agreements. Working Paper.John E. Walker Department of Economics, Clemson University, Clemson, SC 29634 USA.

Baker and McKenzie. 2012. The Global Public Procurement Handbook.

Bloomberg News. 2013. "Vietnam Gets Tough on State Firms in Economic Growth Push" July 25, 2013

Chen, Lurong and Philippe de Lombaerde. 2011. Regional Production Sharing Networks and Hub-Ness in Latin America and East Asia: A Long-Term Perspective. Integration and Trade No. 32: 17-34.

Cheong (2008) "Importance of Market Access in Paving the Way towards anEast Asian FTA", Journal of Korea Trade, December

Cheong, Inkyo and Jungran Cho. 2009. The Impact of Free Trade Agreements (FTAs) on Business in the Republic of Korea. ADBI Working Paper Series No. 156. Asian Development Bank Institute.

Cheong, Inkyo and Jungran Cho. 2011. Reforms of Korea's Trade Adjustment Assistance Program for Its Bilateral Free Trade Agreements with the European Union and the United States, Asian Economic Papers 10:1: 32-55.

Giap. 2013. "ASEAN-10 Competiveness, Impact of Global Growth Engines, Regional Economic Integration through Free Trade Agreements", Asia Competitiveness Institute, Lee Kuan Yew School of Public Policy, National University of Singapore.

Hunter Rodwell Consulting. 2013. "Intellectual Property Rights Primer for Vietnam: A Guide for UK Companies," http://www.ipo.gov.uk/ipr-guide-vietnam.pdf. 
Ko, Jongo and Jungran Cho. 2013. "China's nonmetallic industry and implications for the Korea-China FTA" forthcoming in the Journal of International Logistics and Trade

KPMG. 2013. "Investment in China: Numbers and Trends Third Quarter," KPMG Global China Practice.

KPMG International. 2011. "Product Sourcing in Asia Pacific New locations, extended value chains", viewed at www.kpmg.com

Le Thu Trang. 2012. "State owned enterprises in Vietnam", Policy Design and Implement in Developing Countries

Office of the U.S. Trade Representative. 2012. New Opportunities for U.S. Exporters under the U.S.-Korea Trade Agreement. www.ustr.gov/trade-agreements/free-tradeagrements/ korus-fta. last visit on 01/04/2013.

Petri, Peter and Micheal Plummer. 2012 The Trans-Pacific Partnershipand Asia-Pacific Integration:Policy Implications. Peterson International Economic Institute. June.

Phạm Chi Lan. 2013. "NHIN LẠI 5 NĂM VIỆT NAM GIA NHẬP WTO: Nhữngthànhtựuvàhạnchế"

Rana, Pradumna B. 2012. "A region-wide free trade agreement in Asia".VOX. 25 June

Stratfor. 2013. "The Post-China 16: Ascendant Manufacturing Countries," July 30, viewed at http://www.stratfor.com/image/post-china-16-ascendant-manufacturing-countries.

Tan KheeGiap. 2013. "ASEAN-10 Competiveness, Impact of Global Growth Engines, Regional Economic Integration through Free Trade Agreements "Asia Competitiveness Institute, Lee Kuan Yew School of Public Policy, National University of Singapore

Umada, keiiti and Uratashuziro. 2012. “JapanofTPPstrategy”Bunshindo

Wignaraja, Ganeshan. 2011. ASEAN $+3 /+6$ or TPP? Pathways Towards East Asian FTA Consolidation, ADB Papers. Manila: ADB 